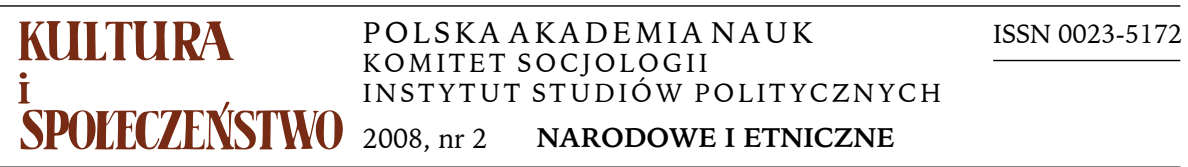

NICOLE DOŁOWY

Uniwersytet Warszawski

\title{
MOŻLIWOŚCI REWITALIZACJI ZAGROŻONYCH JĘZYKÓW: MIĘDZY ODPOWIEDZIALNOŚCIĄ PAŃSTWA A DZIAŁANIAMI MNIEJSZOŚCI JĘZYKOWYCH
}

Polityka językowa większości państw europejskich często aż do drugiej połowy XX wieku była oparta na promowaniu języków „narodowych” kosztem innych języków występujących na terytorium państwa. Postawa ta - prowadząca do marginalizowania roli lub wręcz eliminowania języków mniejszościowych była związana ściśle $z$ dziewiętnastowieczną koncepcją państwa narodowego, bazującego na sile i dominacji jednej grupy kulturowej, narzucającego wszystkim odmiennym grupom poczucie narodowej solidarności. W epoce tworzenia się państwowości europejskich utrzymanie państwa nie opartego na jedności kulturowej i językowej zarazem wydawało się niemożliwe. Jakobińska koncepcja państwa przyczyniła się do powstania opinii, że nowoczesne państwo musi być oparte na wspólnocie narodu i języka. W tego typu myśleniu ujawniają się dwa (co najmniej wątpliwe) przeświadczenia. Według pierwszego, gdy społeczeństwo jest jednojęzyczne, możliwy jest lepszy rozwój ekonomiczny państwa. Według drugiego, narodowa i terytorialna integralność państwa znajduje się w niebezpieczeństwie, jeśli wszyscy obywatele nie należą do jednej kultury i nie mówią tym samym językiem (Skutnabb-Kangas, Phillipson 1995, s. 4). Ta koncepcja jednorodnego państwa była wprowadzana w życie przede wszystkim za pomocą systemu administracyjnego i poprzez szkolnictwo. Działania aparatu państwowego zmierzały więc do likwidacji różnic kulturowych i językowych, co w dużej mierze sprowadzało się do przymusowej asymilacji kulturowej i zakazów posługiwania się w życiu pozadomowym (kościele, szkole, urzędach) językiem mniejszościowym. W ten sposób używanie większości języków niepaństwowych zostało bezwzględnie ograniczone, czego skutkiem jest ich bardzo słaba pozycja, co niekiedy zagraża nawet ich przetrwaniu.

Adres do korespondencji: nicoledolowy@gmail.com 
Według różnych statystyk na świecie istnieje obecnie około sześciu tysięcy języków, z czego gros (96\%) to języki, którymi posługuje się 4\% ludzkości (Crystal 2005, s. 3-15). Większość z nich jest używana przez grupy liczące kilka osób lub co najwyżej kilka tysięcy. Według badaczy i lingwistów jedynie kilkaset spośród języków świata ma szansę przetrwać następne stulecia. Stephen Wurm zaproponował pięciostopniową skalę określającą stan zagrożenia języków. Języki „potencjalnie zagrożone” (potentially endangered) to te, które są społecznie i ekonomicznie marginalizowane, znajdują się pod presją języków silniejszych. Systematycznie maleje liczba dzieci posługujących się nimi. O językach „zagrożonych" (endangered) mówimy wtedy, gdy dzieci nie uczą się danego języka lub gdy liczba najmłodszych znających go gwałtownie maleje, a najmłodszymi osobami posługującymi się nim na co dzień są młodzi dorośli. Najmłodszymi osobami używającymi języków „poważnie zagrożonych” (seriously endangered) są osoby powyżej 50 roku życia. Językami „umierającymi” (moribound) posługuje się jedynie niewielka liczba osób ze wspólnoty kulturowej, której wcześniej te języki były przypisane, zazwyczaj są to ludzie starsi, a językami „wymarłymi” (extinct) nie posługuje się już nikt (Wurm 1998, s. 192). Skala ta uwzględnia przede wszystkim rzeczywiste używanie języka oraz możliwość przekazywania go następnym pokoleniom, a także skład demograficzny grupy znającej dany język. Przyczyn zerwania międzykulturowej transmisji języków można znaleźć wiele.

Języki giną wtedy, gdy umierają osoby posługujące się nimi. Większość języków świata jest używana przez niewielkie grupy. Dla ich przetrwania naturalne katastrofy spotykające wspólnotę językową, takie jak lawiny, erupcje wulkanów, powodzie, ale też epidemie, susze czy głód, stanowią bardzo istotne zagrożenie. Mogą doprowadzić do wyginięcia wszystkich użytkowników danego języka lub do rozproszenia się ich po innych terytoriach.

Języki są zagrożone także na skutek asymilacji kulturowej i językowej ich użytkowników. Przyczynami przechodzenia na inne języki mogą być podboje czy przymusowe przesiedlenia. Inną przyczyną mogą być fale emigracyjne lub wewnątrzpaństwowe migracje ludności powodujące rozbicie wspólnot, poza którymi używanie języka mniejszościowego nie jest możliwe. Równie groźna jest zmiana sposobu życia użytkowników języka, otwarcie się dotychczas hermetycznych wspólnot kulturowych na wpływy kultury dominującej, częste zwłaszcza w następstwie procesów industrializacji, stosowania nowych technologii ( $z$ czym wiąże się zerwanie $z$ tradycyjnymi czynnościami), wreszcie wpływu mediów w języku dominującym.

Języki giną również wtedy, gdy ludzie posługujący się nimi nie chcą już ich używać. Zmiana językowa może nastąpić w konsekwencji zorganizowanych działań państwa wymierzonych we wspólnotę językową i nastawionych na asymilację kulturową i językową danej grupy przez przymusowe szkolnictwo $\mathrm{w}$ języku dominującym, stosowanie kar za posługiwanie się w miejscach publicznych językiem mniejszościowym, wykluczenie tego języka z życia publicznego. Działania mogą też zmierzać do obniżenia prestiżu języków mniejszo- 
ściowych przez marginalizowanie grupy mniejszościowej, kojarzenie jej w publicznych dyskursach z kulturą gorszą, wiejską, kulturą nieprzystającą do wymogów współczesnego świata. Powstanie tego typu skojarzeń może wywołać u przedstawicieli grup mniejszościowych poczucie wstydu i chęć porzucenia swojego języka i kultury na rzecz kultury dominującej. Język mniejszościowy zaczyna być wtedy uważany za obciążenie, a posługiwanie się nim może wydawać się przeszkodą $\mathrm{w}$ osiągnięciu sukcesu $\mathrm{w}$ życiu. Język mniejszości jest powoli wykluczany ze wszystkich sfer życia pozadomowego, przestaje być używany w czynnościach związanych z nowoczesnym życiem (media, przemysł, prawo), tym samym nie tworzy się nowe słownictwo. Następuje powolna „folkloryzacja"(Fishman 1987, s. 1-15) języka i kultury mniejszościowej, traktowanej często jako relikt przeszłości czy zjawisko etnograficzne, a nie pełnoprawna kultura.

Wielu badaczy sądzi, że do języków niezagrożonych należą jedynie te, które mają w państwie oficjalny status. Michael Krauss podaje, że spośród wszystkich języków świata jedynie 250 jest rozpoznanych jako języki oficjalne, państwowe lub współoficjalne na terytorium swojego występowania (Krauss 1992, s. 4 -10). Tym samym języki mające oficjalny status w państwach lub autonomicznych regionach stanowią mniej niż 5\% wszystkich języków świata (Martí i in. 2005, s. 98). Oficjalny status zapewnia językom zaistnienie w życiu oficjalnym, regulacje państwowe otaczają je ochroną, ale przede wszystkim dzięki oficjalizacji może zmienić się nastawienie zwykłych ludzi do możliwości i sensu ich używania, podnosi się ich prestiż, a przez to chęć identyfikacji z nimi. Claude Hagège (2000) uważa, że nadanie językowi oficjalnego statusu poprzez uwzględnienie specyficznych praw dla jego użytkowników jest warunkiem koniecznym jego ochrony i promocji, a tym samym przetrwania.

$\mathrm{W}$ tę stronę idzie też coraz więcej państw europejskich, decydując się na oficjalizację wszystkich lub niektórych języków mniejszościowych występujących na ich terytoriach. Każde $z$ tych państw wprowadza w życie różnego typu regulacje i inaczej definiuje status i prawa językowe grup mniejszościowych, jak również stosuje inną politykę językową, jednak nadrzędnym celem tych działań jest zrównanie praw języków mniejszościowych z językiem dominującym. Jako pierwsze taką politykę wprowadziły Szwajcaria i Irlandia (w Szwajcarii równoprawnymi językami są niemiecki, francuski, włoski i retoromański, w Irlandii zaś angielski i irlandzki), w ślad za nimi poszły między innymi Luksemburg (francuski, niemiecki i luksemburski) czy Belgia (francuski, niemiecki i niderlandzki). Inne państwa, nie czyniąc języków mniejszościowych oficjalnymi w państwie, nadają im status współoficjalny na terytorium ich występowania. Jako przykład można podać Hiszpanię (język baskijski, kataloński i galicyjski) czy Danię (język farerski). Mimo tych przykładów wiele państw wciąż nie decyduje się na uwzględnienie praw językowych swoich mniejszości, a inne, nawet gwarantując te prawa, nie czynią żadnych kroków, aby rzeczywiście promować czy utrzymać języki mniejszościowe. 
Ostatnie kilkadziesiąt lat upływa pod znakiem przemian w prawie międzynarodowym, a także specyficznych regulacji europejskich dotyczących respektowania podstawowych praw językowych. Tylko w Europie żyje około 40 milionów ludzi używających języków mniejszościowych. Daje to około 10\% populacji Unii Europejskiej (dane szacunkowe za: Martí i in. 2005, s. 107). Jednak rzeczywiste prawa w Unii mają wyłącznie języki państwowe. Choć w oficjalnych międzynarodowych konwencjach i deklaracjach (takich jak Uniwersalna deklaracja praw jezykowych, UNESCO, 1996) uznaje się prawo wszystkich ludzi do języka ojczystego, możliwość nauki tego języka, prawo dzieci do edukacji w tym języku i prawo do posługiwania się nim w oficjalnych sytuacjach (w szkole, w pracy, w życiu publicznym), a także do wolnego wyboru między językiem oficjalnym a ojczystym, to rezolucje te nie mają realnego wpływu na status języka ani znaczenia dla mniejszości językowych, gdyż nie obligują państw do ich respektowania.

Rada Europy również wprowadza międzynarodowe przepisy regulujące prawa mniejszości językowych, podkreślając fakt, że różnorodność kulturowa i językowa jest największym bogactwem naszego kontynentu. W tym celu zostały wprowadzone regulacje, spisane w Europejskiej karcie języków regionalnych lub mniejszościowych (1992), który to dokument został następnie przedłożony państwom europejskim do podpisania. Warto jednak zaznaczyć, że jego podpisanie i ratyfikowanie nie jest obowiązkowe nawet dla państw członkowskich Unii Europejskiej (choć od nowo przyjmowanych do UE państw wymaga się wprowadzenia odpowiednich zmian $\mathrm{w}$ konstytucji), a sam sposób sformułowania dokumentu pozwala państwom na dużą dowolność w wypełnianiu podpisanych zobowiązań. Przede wszystkim państwa podpisujące dokument same wyznaczają, które mniejszości językowe będą obejmowane ochroną. Co więcej, państwo wybiera, które paragrafy i punkty będzie realizować (wymagane jest podpisanie przynajmniej 35 punktów). Celem takiego ujęcia było ułatwienie państwom podjęcia decyzji o podpisaniu Europejskiej karty języków. Jednak sformułowanie jedynie ogólnych zobowiązań, bez wyznaczenia referencji do poszczególnych języków, sprawiło, że dokument ten ma znaczenie czysto symboliczne (Martí i in. 2005, s. 107). Z formalnego punktu widzenia można go skrytykować także za nieprecyzyjność sformułowań. Tove Skutnabb-Kangas i Robert Phillipson zwracają uwagę, że sformułowania zawierają sporą liczbę nieprecyzyjnych pojęć, takich jak: „W stopniu, w jakim jest to możliwe”, „uzasadnione”, „W rozsądnych granicach”, „tam, gdzie jest to konieczne”, „dzieci, których rodziny sobie tego życzą i których liczba jest uważana za wystarczającą”, ,jeśli liczba osób posługujących się językami regionalnymi lub mniejszościowymi to uzasadnia”, jak również wiele alternatyw: „do zezwalania, zachęcania lub zapewnienia nauczania $\mathrm{w}$ języku regionalnym lub mniejszościowym, lub też nauczania o tym języku odpowiednio na wszystkich poziomach". W ten sposób państwa mogą stosować podpisane zobowiązania w minimalnym stopniu, twierdząc, że warunki nie były „wystarczające” czy „możliwe do speł- 
nienia” albo „odpowiednie”, liczba osób nie była „wystarczająca” czy też „nie usprawiedliwiała” wydatków ze strony państwa, „umożliwiając” jednocześnie mniejszości zorganizowanie nauczania języka na własny koszt (Skutnabb-Kangas, Phillipson 1995, s. 91). Jednak mimo tych krytycznych uwag należy podkreślić ważną rolę, którą odgrywa ten dokument - wymaga od rządów państw go ratyfikujących podjęcia minimum działań na rzecz języków mniejszościowych w szkolnictwie, mediach, życiu kulturalnym, publicznym i administracji, a przede wszystkim uznania wielojęzycznej rzeczywistości i wykazania dobrej woli jej ochrony i promocji. I dlatego też jego opracowanie powinno być uznane za istotny krok naprzód, pod warunkiem że przyjęte postanowienia będą respektowane i wdrażane (Martí 2005 i in., s. 107).

Nawet przychylna postawa państw wobec mniejszości językowych może przybierać kształt różnych rozwiązań. Stephen May rozróżnia dwa typy praw językowych. Pierwszy obejmuje prawa odwołujące się do tolerancji, zapewniające możliwości używania języka w życiu prywatnym i w pozarządowej sferze życia narodowego. Prawa te mogą być rozumiane wąsko lub szeroko. Zawiera się $\mathrm{w}$ nich prawo jednostki do posługiwania się językiem $\mathrm{w}$ sferze prywatnej i publicznej, wolność zgromadzeń i organizacji, prawo tworzenia instytucji kulturowych, ekonomicznych i społecznych, w których pierwszym językiem może być język mniejszości, a także prawo do nauki tego języka w prywatnych szkołach. Prawa drugiego typu — zorientowane na promocję — odnoszą się do uznania możliwości używania języka mniejszości w życiu publicznym, w sądownictwie i państwowych urzędach. I te prawa mogą jednak być rozumiane dwojako. W rozumieniu najwęższym mogą sprowadzać się do możliwości publikowania dokumentów w języku mniejszości, a w rozumieniu najszerszym mogą oznaczać uznanie języka mniejszości za język oficjalny państwa lub współoficjalny na terenie jego występowania (May 2001, s. 1983).

Niezależnie od różnic prawnych państwo „tolerując” języki może - jak w przypadku Walii - zapewnić im rzeczywiste i adekwatne środki promocji, rozwoju i ochrony albo też może uznać wszystkie języki występujące na jego terytorium za oficjalne, nie wyznaczając jednak żadnych rzeczywistych środków, aby je promować. Odpowiedzialność za języki mniejszościowe i etniczne znajdujące się na terytorium państw europejskich ponoszą więc same grupy językowe, a państwa w zasadzie przed nikim za ich respektowanie nie odpowiadają (czego najlepszym przykładem może być postawa Francji i Grecji, a także brak reakcji pozostałych państw europejskich wobec braku poszanowania przez nie praw mniejszości kulturowych i językowych). Jednak nawet gdyby państwa uwzględniły rezolucje w sprawie praw językowych, sam zapis prawny czy podpisanie międzynarodowych konwencji nie wystarczają, by mniejszości językowe mogły swobodnie posługiwać się swoim językiem. Potrzebna jest swego rodzaju „pozytywna dyskryminacja”, a więc stwarzanie takich uregulowań prawnych, które preferują mniejszości kulturowe i językowe (Różyca 2003, s. 489). 
Mimo braku dokładnych regulacji sytuacja wielu języków mniejszościowych na terytorium Europy w ostatnich dziesięcioleciach ulega zmianie. Ruch odnowy językowej i etnicznej (linguistic and ethnic revival), zapoczątkowany w latach sześćdziesiątych XX wieku, zaowocował wzrostem samoświadomości przedstawicieli wielu kultur mniejszościowych i wywołał szereg następstw, a także bardziej lub mniej skutecznych działań ze strony przedstawicieli tych mniejszości. Te działania z kolei niejednokrotnie wymusiły na władzach państwowych podjęcie odpowiednich kroków w celu uregulowania niepewnego statusu owych mniejszości.

Nie istnieje jeden skuteczny sposób ani właściwy schemat przeciwdziałania upadkowi języków mniejszościowych, nawet jeśli ograniczymy się do terytorium Europy. Nie wszystkie mniejszości językowe mają jakiekolwiek materiały pedagogiczne i wyszkolonych nauczycieli swoich języków, a prowadzone już na świecie procesy rewitalizacji z różnych względów mogą nie wystarczać jako wzór (Hinton, Hale 2001, s. 4). Języki mniejszościowe, które nie mają oparcia $\mathrm{w}$ organizmach państwowych, te, których istnienie i przetrwanie zależne jest wyłącznie od samoorganizacji ${ }^{1}$, funkcjonują bowiem $\mathrm{w}$ różnych uwarunkowaniach, stopień ich zagrożenia jest niejednakowy. W zasadzie każdy przypadek ginącego języka należałoby analizować osobno. Wpływ ma wiele czynników, takich jak historia mniejszości i stopień odejścia od języka, stopień utraty przez język prestiżu, a co za tym idzie - odczuwanie wstydu z powodu przynależności do grupy, chęć wyparcia się swoich korzeni przez członków kultur mniejszościowych i asymilacja $z$ kulturą większościową. Jednocześnie mamy do czynienia ze zmianą sposobu życia, migracją wewnętrzną i zewnętrzną przedstawicieli kultur mniejszościowych. Różne jest położenie ekonomiczne regionów. W innej sytuacji znajdują się mniejszości mające tradycje piśmienne, materiały edukacyjne, literaturę we własnym języku (np. Bretończycy, Baskowie, Łużyczanie), w innej - te, które dopiero dokonują standaryzacji i kodyfikacji języka, poszukując formy nauczania dzieci w szkołach (język gallo w Bretanii, język kaszubski). Inna jest sytuacja języka, który był kiedyś językiem wpływowym i miał zagwarantowane miejsce w zbiorowych praktykach społeczności (Kościół, szkoła), inna - jeśli do takich praktyk jest dopiero wprowadzany. Ogromny wpływ na ochronę języka ma także jego status: czy jest uznany przez własną zbiorowość i przez językoznawców za „język” czy za „dialekt języka państwowego". Podział ten, jak uważa wielu badaczy zajmujących się problemami ginących języków, często służy marginalizacji roli języka używanego przez mniejszość, pozwalając myśleć, że jest to niższa forma, gorszy sposób

1 W odróżnieniu od języków mniejszości, które mają oparcie w innych organizmach państwowych (np. mniejszość litewska w Polsce czy duńska w Niemczech). W innej sytuacji znajdują się także mniejszości, które zamieszkują na terytorium kilku państw, przynajmniej w jednym z nich mając mocną pozycję (np. Baskowie w Hiszpanii i Francji). 
komunikacji. „Dialekty (języki rodzime [vernacular] czy patois ${ }^{2}$ ) są uznawane za niewystarczająco rozwinięte, aby pełnić oficjalne funkcje w narodzie czy państwie. Tym samym polityka językowa, która pozbawia je uznania, pozbawia je także środków budowania własnego potencjału" (Skutnabb-Kangas, Phillipson 1996, s. 671-672). Ogromne znaczenie ma wreszcie zaangażowanie i pomoc ze strony państwa, na którego terytorium mniejszości się znajdują, wsparcie finansowe i instytucjonalne dla podejmowanych przez nie działań (lub ich brak).

Możliwość przetrwania języków zależy od wielu różnych czynników. Do najważniejszych można zaliczyć: liczbę osób znających ten język i stopień ich skupienia, ich socjoekonomiczny status, zakres i typ transmisji językowej, zaangażowanie wspólnoty w projekty ochrony języka, stopień standaryzacji tego języka, jego status, prawa językowe grupy oraz stosunek państwa (czy uznany jest za język oficjalny lub współoficjalny, czy państwo wspiera wysiłki na rzecz jego ratowania), stosunek ludzi do tego języka, charakter związku języka i tożsamości kulturowej grupy, stosunek większości do mniejszości językowej, historia tej grupy językowej (a także języka obszaru, na którym występuje), czynniki związane $z$ obszarem, na którym żyje mniejszość językowa (czy obszar ten jest autonomiczną jednostką administracyjną czy też jest częścią większej całości i trudno wyznaczyć jego granice), życie religijne wspólnoty (czy Kościół wspiera dążenia grupy do zachowania swojego języka), edukacja (czy język jest nauczany w szkołach, czy jest nauczany jako język drugi, język obcy, czy jest językiem wykładowym), sytuacja ekonomiczna grupy językowej (związki między zachowaniem języka i sytuacją życiową i ekonomiczną grupy), media (czy język obecny jest $\mathrm{w}$ mediach, czy istnieją media przeznaczone wyłącznie dla danej grupy, czy są to pojedyncze programy, teksty $\mathrm{w}$ mediach posługujących się językiem dominującym), stopień rozwoju wewnętrznej organizacji (czy istnieją organizacje mniejszości zajmujące się sprawami edukacji, kultury, planowaniem językowym, badaniami naukowymi) itd. ${ }^{3}$

Badacze zajmujący się „odwracaniem zmiany językowej” (reversing language shift) zwracają uwagę, że najważniejsza w procesie zachowania języka jest jego transmisja międzypokoleniowa i stworzenie odpowiednich warunków do używania go, znacznie bardziej niż jego oficjalizacja, która w przypadku wielu języków europejskich wciąż jest utopijna. Bardzo często jednak te dwa postulaty uzupełniają się, gdyż uznanie przez państwo prawa ludzi do posługiwania się ich ojczystym językiem w różnych sytuacjach, zarówno prywatnych, jak i publicznych, potwierdza status języka i stwarza mu możliwość rozwoju.

Nie zawsze jednak wyjście od oficjalizacji języka pomaga rozwiązać problem. Zupełnie inna jest bowiem sytuacja języków mniejszościowych, w któ-

2 Francuski termin patois oznacza „gwarę, narzecze, żargon” i jest bardzo silnie nacechowany negatywnie i lekceważąco.

${ }^{3}$ Możliwością przetrwania języków zajmuje się wielu badaczy; zob. m.in.: Edwards1992; Hyltenstam, Stroud 1996. 
rych wciąż istnieje transmisja międzypokoleniowa (nawet jeśli jest zubożona), a inna w przypadku języków, które w praktyce nie są już przekazywane z pokolenia na pokolenie, a ludzie jeszcze się nimi posługujący w codziennym życiu należą do najstarszego pokolenia. Co więcej, często trudno wyodrębnić teren, na którym zamieszkuje mniejszość językowa, zwłaszcza ze względu na wewnątrzpaństwowe migracje. Dlatego też w niektórych przypadkach nawet określenie wspólnoty objętej specyficznymi prawami językowymi może być trudne. Nie wszyscy przedstawiciele kultur mniejszościowych nadal się z nimi identyfikują, nie dla wszystkich język mniejszościowy ma znaczenie języka ojczystego. Często naturalna transmisja języka mniejszościowego została przerwana kilka pokoleń temu, a więc dla młodych językiem pierwszym (a często jedynym) jest oficjalny język państwowy. Praktycy podejmujący działania służące zmianie sytuacji języków zagrożonych twierdzą jednak zgodnie, że niezależnie od sytuacji języka, pierwszym krokiem do zmiany, odwrócenia czy zahamowania procesu odchodzenia od języka powinno być uświadamianie ludziom, że językiem mniejszościowym warto mówić, że ten język jest sam w sobie wartością, a jego śmierć będzie ogromną stratą dla ludzkiego dziedzictwa kulturowego. Tak formułowane argumenty mogą jednak nie być przekonujące dla członków mniejszości językowych. Większość programów rewitalizacyjnych jest zatem nastawiona na konkretne działania zmieniające stosunek przedstawicieli mniejszości do ich języków, nie zaś na słowną agitację. Nie można porównywać (jak niektórzy wciąż czynią) ratowania ginącego języka do ratowania ginącego gatunku roślin lub zwierząt. Języki nie są bowiem przedmiotami, które można uratować, ale istnieją $\mathrm{w}$ procesie społecznej interakcji, jako nieodłączny składnik życia danej grupy. Jeśli dany sposób komunikacji przestaje spełniać swoje zadania i wspólnota przestaje używać języka, to samo przekonywanie ze strony lingwistów, edukatorów czy polityków nie zmieni postawy ludzi wobec tego języka, a tym samym nie uratuje się go. Bardzo często w publicznym czy naukowym dyskursie na temat problemów zagrożonych języków dominuje przedmiotowe traktowanie ich nosicieli. Niejednokrotnie można przeczytać, że „język zginął przez niesprzyjającą politykę państwa, rozwój mediów, dostęp do edukacji itd." Tymczasem wszystkie te czynniki, choć rzeczywiście w ogromnym stopniu przyczyniają się do wypierania „małych języków” przez dominujące, nie mają bezpośredniego wpływu na język, a właśnie na jego użytkowników. To oni podejmują decyzję (niekiedy pod przymusem, innym razem sami wybierając inną drogę życiową dla siebie i swoich rodzin), że w danym języku nie będą mówić. A język istnieje tylko wtedy, gdy żyją osoby posługujące się nim ${ }^{4}$. Jednak proponowana czasem recepta, aby wszyscy członkowie mniejszości mówili

4 Oczywiście, możemy też mówić o językach „uśpionych”, istniejących w formie spisanej lub nagranej, którymi jednak nikt się nie posługuje. Ich status można wtedy uznać za pośredni. Podejmowane są zresztą, niekiedy z sukcesem, próby „obudzenia” tych języków. Przykładem udanym może być język hebrajski, mniej udanym — kornwalijski. 
językiem mniejszościowym albo aby wszystkie osoby zamieszkujące na danym terenie posługiwały się tym językiem $w$ sprawach oficjalnych lub uczyły się go w szkołach, jest sprzeczna z prawami człowieka, gwarantującymi wolny wybór języka. Takie odgórne „ratowanie” języka mogłoby przynieść efekty odwrotne do zamierzonych i doprowadzić do zamienienia danego obszaru w „rezerwat językowy".

Jak pokazują przykłady wielu zagrożonych języków, odwrócenie procesu zmiany językowej jest możliwe. Działania w tym zakresie muszą podejmować osoby, które chcą posługiwać się danym językiem i którym stwarza się ku temu możliwości. Działania takie nie mogą jednak polegać na „zmuszaniu” ludzi do posługiwania się językiem mniejszościowym (byłyby to bowiem działania analogiczne do tych, które podejmowali wcześniej przedstawiciele kultury dominującej), lecz na skutecznych akcjach zachęcających do używania tego języka. Muszą w nie być zaangażowani wszyscy (lub większość) przedstawiciele kultur mniejszościowych, co oczywiście oznacza dla nich wiele poświęceń, na które nie zawsze będą chcieli się zgodzić. Gdy jednak odpowiedzialność za ratowanie języka zostaje zrzucona na kilka jednostek (działaczy, nauczycieli) albo na sztucznie wprowadzane przepisy odgórnie regulujące prawa posługiwania się językiem, to język ten zostaje skazany na wyginięcie. Jedynie wspólnota językowa (która może - i powinna - być otwarta na osoby pragnące uczestniczyć $\mathrm{w}$ tym procesie) jest w stanie zainicjować wysiłki mające na celu umacnianie pozycji języka mniejszościowego, jeśli jakiekolwiek odgórne (rządowe, edukacyjne itd.) programy mają mieć rzeczywiste szanse sukcesu.

François Grin wymienia trzy warunki konieczne, aby wspólnota językowa mogła posługiwać się swoim językiem, a tym samym, by język ten pozostał żywym środkiem komunikacji. Pierwszym warunkiem jest zdolność do (capacity) używania języka, rozumiana jako wystarczający stopień kompetencji językowej - członkowie wspólnoty językowej (oraz inni, którzy niekoniecznie się z tą wspólnotą identyfikują) muszą znać język, a jeśli go nie znają lub znają w stopniu uniemożliwiającym swobodną komunikację, muszą mieć możliwość nauczenia się go. Drugi warunek uwypukla fakt, że nawet jeśli przedstawiciele wspólnoty językowej znają język i chcą go używać, muszą mieć ku temu s pos obn ość (opportunity). Możliwość nie ograniczającą się do wyboru języka w zaciszu domowym, ale także we wszystkich sferach życia publicznego (i tu część ciężaru odpowiedzialności spoczywa na regulacjach prawnych ze strony państwa). Trzeci - i chyba najważniejszy - warunek dotyczy bezpośrednio zaangażowania jednostek: przedstawiciele wspólnot językowych będą używać swojego języka tylko, jeśli tego pragną (desire). Jest to tym ważniejsze, że zazwyczaj przedstawiciele mniejszości językowych są dwujęzyczni, co oznacza, że mogą bez problemu w każdej sytuacji posługiwać się językiem większości. Jeśli natomiast mają wybór między użyciem jednego $z$ dwóch języków i jeśli ten wybór ma być dokonany na korzyść języka mniejszościowego, to musi istnieć wyjątkowo silne pragnienie lub chęć, żeby właśnie tym językiem się posłużyć 
(Grin 2003, s. 43-44). Jest to kwestia postaw ludzi względem języka. Od nich samych bowiem zależy, czy będą chcieli posługiwać się językiem, przekazać go swoim dzieciom, użyć go w sytuacji pozadomowej. A od tego, czy ludzie wstydzą się swojego języka, czy z używaniem go wiążą się negatywne czy pozytywne wspomnienia, niejednokrotnie zależy stosowanie go $\mathrm{w}$ kontaktach $z$ innymi osobami. Często język mniejszościowy jest związany w powszechnym wyobrażeniu z niskim prestiżem używającej go wspólnoty językowej, co powoduje, że osoby, które mogłyby potencjalnie się nim posługiwać, jako środek komunikacji wybierają inny język, zazwyczaj dominujący. Niejednokrotnie wiąże się to też z decyzją, aby swojemu dziecku nie przekazywać tego języka, a tym samym umożliwić mu lepszy start czy zaoszczędzić niemiłych i nierzadko upokarzających przeżyć, jakie stały się udziałem rodziców ${ }^{5}$. Języki mają taką pozycję, jaką mają ich użytkownicy. Jeśli ludzie posługujący się językiem mają władzę i prestiż, także język ma prestiż; jeśli jest inaczej, także język jest zazwyczaj źle postrzegany (Dorian 1998, s. 3-4).

Jednak pozycja i prestiż języków (jak i społeczeństw) nie są dane raz na zawsze. Ostatnie kilkadziesiąt lat przyczyniło się nie tylko do powstania międzynarodowych konwencji dotyczących praw językowych, konieczności ochrony języków regionalnych czy mniejszościowych, praw mniejszości itd., stworzono także międzynarodowe agencje i organizacje pozarządowe, których celem jest $z$ jednej strony monitorowanie sytuacji języków mniejszościowych na świecie (czy w Europie), z drugiej zaś lobbing na rzecz tych języków we władzach międzynarodowych. Organizacją międzynarodową propagującą bogactwo i różnorodność kulturową świata jest UNESCO, w którego deklaracjach języki i prawa językowe osób odgrywają ważną rolę. Do najważniejszych organizacji europejskich, których celem jest ochrona europejskiego dziedzictwa kulturowego, należy European Bureau for Lesser-Used Languages (EBLUL) — choć w ostatnich latach utraciło ono znacznie możliwości finansowe, nadal pozostaje podstawową instancją dla mniej rozpowszechnionych języków Europy. Istnieje także znaczna liczba organizacji pozarządowych, których zadania koncentrują się albo na inicjowaniu konkretnych działań na rzecz zagrożonych języków, albo też na konsekwentnym opisywaniu problemów tych języków, a przez to na ich nagłaśnianiu i wywieraniu na przedstawicielach rządów presji, by uwzględnili w swych projektach mniejszości językowe ${ }^{6}$.

Wydaje się, że najważniejszym skutkiem działań tych organizacji była zmiana w zakresie dyskursu dotyczącego języków mniejszościowych i wspólnot językowych. Na tym gruncie podjęto wiele zorganizowanych działań, powstało

${ }^{5}$ Przykłady można znaleźć w niemal każdej europejskiej mniejszości językowej, choćby całkowite przerwanie w latach pięćdziesiątych XX wieku międzypokoleniowej transmisji języka bretońskiego na rzecz francuskiego; zob. Broudic 1995.

6 Oto kilka takich organizacji: Eurolang (www.eurolang.net), Ethnologue (www.ethnologue. com), Euromosaic (www.uoc.edu/euromosaic/), Foundation for Endangered Languages (www. ogmios.org), Linguasphere (www.linguasphere.org), Mercator (www.mercator-central.org) itd. 
wiele ruchów mniejszościowych, które zaczęły głośno domagać się swoich praw. Zwrócenie uwagi na realne zagrożenie zniknięciem większości języków świata w ciągu następnego stulecia, a także głośne postulowanie konieczności ich ochrony, a przede wszystkim odpowiedzialności państw, na których terytorium znajdują się mniejszości językowe, za ich przetrwanie, sprawiło, że oficjalny dyskurs państw, które chcą mieć w świecie znaczenie i respekt, musiał ulec zmianie. Obecnie nawet te państwa, które nic nie zmieniły w zakresie praw językowych swoich obywateli ani nie uwzględniły praw mniejszości językowych w swoich konstytucjach, dają mniejszościom coraz większą autonomię kulturową i językową, nawet jeśli sprowadza się to do wspierania finansowego instytucji mniejszości lub dopuszczenia używania języka mniejszości w edukacji. Przedstawiciele władz pilnują się także, aby w publicznych przemówieniach uwzględniać znaczenie „małych” języków państwa. Jeszcze kilkadziesiąt lat temu sformułowania takie jak to z 1972 r., gdy George Pompidou mówił: „Nie ma miejsca dla języków i kultur regionalnych we Francji, która musi wywrzeć na Europie swoje piętno" (cyt. za: Abalain 2000, s. 45), były na porządku dziennym. Obecnie nawet $w$ negatywnie nastawionej do mniejszości językowych Francji takie wypowiedzi w dyskursie publicznym nie mogłyby się pojawić, gdyż wiązałoby się to $z$ napiętnowaniem przez społeczność międzynarodową. Drugą, znacznie ważniejszą z perspektywy ratowania ginących języków konsekwencją zmiany dyskursu jest przyciągnięcie do ruchów mniejszościowych znacznej liczby osób. Wspólnoty językowe zaczęły się aktywizować, gdyż „ginące języki" oraz przynależność do mniejszości kulturowej czy językowej stały się modne. Przychylny dyskurs, podnoszący w oczach przedstawicieli mniejszości prestiż ich językowi i kulturze, sprawia, że coraz więcej osób z własnej woli włącza się w działania na rzecz ochrony języków, co dla ich przetrwania ma kolosalne znaczenie. Przecież jedynie pragnienie posługiwania się językiem przez daną mniejszość i podejmowane przez nią samą działania mogą doprowadzić do rzeczywistego sukcesu programów „odwracania zmiany językowej”.

Aby sukces ten był możliwy, jego potencjalni sprawcy muszą być świadomi możliwości posługiwania się językiem zagrożonym i muszą chcieć się nim posługiwać. W warunkach współczesnego świata ten drugi postulat wydaje się, paradoksalnie, trudniejszy do spełnienia niż pierwszy. Dlatego właśnie potrzeba wielu oddolnych akcji zwracających uwagę nie tylko na ważność ratowania języka, ale przede wszystkim na możliwość używania go, a co za tym idzie - identyfikację z nim i ze wspólnotą mniejszościową. Różne przykłady (np. Irlandii) wskazują, że oficjalizacja języka albo nadanie mu odgórnych praw nie ma wystarczającego wpływu na używanie go przez ludzi. Wiele grup stawia wciąż na narodowe lub międzynarodowe konwencje, bardziej niż na lokalne działania. Często jednak zbyt dużą wagę przywiązuje się do oficjalnej polityki, co przy braku konkretnych działań na niższym poziomie może mieć dla języków mniejszościowych skutki sprzeczne z założonymi. I choć zapewnienie obecności języka w miejscu pracy, rządzie i w edukacji stanowi końcowy cel działań 
mających na celu odrodzenie języka i jego utrzymanie, nie jest ono priorytetem (Nettle, Romanie 2000, s. 178).

Joshua Fishman, pionier nauki o możliwościach i sposobach odwracania zmiany językowej i rewitalizacji zagrożonych języków, stworzył ośmiostopniową skalę działań, które - jego zdaniem - powinny być podejmowane wobec mniejszości językowej i przez nią samą (The Gradem Intergenerational Dislocation Scale; zob. Fishman 1991). Zagrożone języki, w zależności od stopnia ich rzeczywistego używania, można umieścić na jednym z ośmiu poziomów, przy czym im język jest bardziej zagrożony i mniej używany, tym dalej plasuje się na skali Fishmana. Cztery końcowe stopnie skali Fishmana dotyczą sytuacji, gdy język mniejszościowy używany jest marginalnie, jedynie przez niektóre grupy osób, a działania skierowane są na zaistnienie dyglosji językowej. Są to: konieczność rekonstrukcji języka, stworzenie bazy słownictwa, często jego standaryzacja, nawiązywanie kontaktów z przedstawicielami najstarszego pokolenia, którzy wciąż posługują się językiem mniejszościowym, jeśli jest to możliwe (stadium 6) - wzmocnienie transmisji językowej i związków wspólnotowych dom-rodzina-sąsiedztwo, wreszcie wprowadzenie elementów nauki języka dla chcących się go uczyć. Z kolei początkowe punkty skali dotyczą sytuacji, w której językiem mniejszościowym znaczna liczba osób wciąż posługuje się w nieformalnych sytuacjach, jednak traci on swój prestiż i coraz rzadziej jest przekazywany następnym pokoleniom. Zdaniem Fishmana, działania powinny być wówczas oparte najpierw na organizacji edukacji języka mniejszościowego i kultury z nim związanej (także dla chcących uczestniczyć $\mathrm{w}$ tym procesie przedstawicieli kultury dominującej), a następnie polegać na wprowadzeniu języka do lokalnych/regionalnych (ale już nie tylko sąsiedzkich) sfer pracy oraz na dążeniu do jego zaistnienia w lokalnych/regionalnych mediach oraz urzędach. Oficjalizacja języka i upowszechnianie go w skali państwowej znajdują się na ostatniej (nr 1) pozycji w skali odwracania zmiany językowej. Propozycje działań poparte są konkretnymi przykładami mniejszości językowych czyniących starania, aby ochronić swój język. W dziesięć lat po opracowaniu teorii reversing language shift badacze ginących języków i przedstawiciele mniejszości językowych zebrali się, aby przedstawić obecny stan opisywanych wcześniej języków. Przykłady te potwierdziły obie, pozornie wykluczające się tezy: że teoria Fishmana sprawdza się w praktyce oraz że każdy przypadek zagrożonego języka wymaga innych metod i narzędzi (zob. Fishman 2001).

Fishman twierdzi, że nie zapewniając wcześniej językowi miejsca w społeczeństwie, nie da się odwrócić procesu utraty języka. Stawiając sobie wygórowane zadania, ale nie przywiązując wystarczającej wagi do małych sukcesów, można niczego nie osiągnąć. Jak pisze: „polityka językowa względem zagrożonych języków musi na początku skoncentrować się na podstawowych, prywatnych funkcjach języka i, jeśli to możliwe, bazując na tej sferze, zbudować połączenia między pierwszymi i następnymi instytucjami międzypokoleniowej ciągłości przekazywania języka. Praca nad tą sferą jest koniecznością; każde 
bardziej zaawansowane działanie jest możliwością. Zaistnienie dyglosji (ze sferami zarezerwowanymi dla zagrożonego języka) jest koniecznością; autonomia ekonomiczna czy polityczna niezależność są możliwościami. Powszechne odbudowanie podstawowych funkcji języka jest koniecznością; wejście języka do wyższych sfer władzy i nowoczesności to możliwości" (Fishman 1989, s. 401). Oczywiście Fishman nie neguje wagi oficjalizacji języka i zrównania jego praw $z$ językiem państwowym. Oficjalizacja jest jednak ostatnim stopniem procesu odwrócenia upadku języka i zapewnienia mu trwalszego (bo praca nad językami mniejszościowymi nie ustaje nawet $\mathrm{w}$ momencie oficjalizacji) miejsca i pozycji w państwie.

Ogromną rolę działań adresowanych bezpośrednio do wspólnoty językowej podkreśla François Grin, twierdząc, że nawet dobrze opracowany program rewitalizacji zawiedzie, jeśli będzie ignorowana rola przedstawicieli mniejszości językowych. Na plan pierwszy wysuwa rolę organizacji, która wzięłaby na siebie odpowiedzialność za politykę językową. „Nawet pobieżny przegląd najbardziej zachęcających przykładów rewitalizacji języków pokazuje, że sukces jest trudny do osiągnięcia, jeśli brak — poza innymi czynnikami - wyspecjalizowanej agencji odpowiedzialnej za rozwój, wprowadzanie i monitorowanie polityki językowej. Przyglądając się przykładom europejskim, należy wskazać na znaczenie Bwrdd yr Iaith Gymraeg (Welsh Language Board) w Walii, Direcció general de política lingüística w Katalonii czy Hizkuntza Politikarako Sailordetza w Kraju Basków. Założenie biura zajmującego się polityką językową nie gwarantuje sukcesu, ale z pewnością pomaga zapewnić warunki sprzyjające rozwojowi polityki językowej" (Grin 2003, s. 199).

Za wzór języka, któremu udało się odwrócić zmianę językową, można uznać walijski. Jego pozycja w Walii znacznie się umocniła, a bardzo szybki spadek transmisji międzypokoleniowej udało się zmniejszyć. Angielski używany jest tu przez wszystkich i stanowi główny język komunikacji, jednak oficjalnie Walia jest dwujęzyczna, około $21 \%$ mieszkańców posługuje się walijskim i znaczny odsetek (zwłaszcza młodych ludzi) opanował podstawy języka walijskiego. Walijski jest dobrym przykładem tego, że silne przywiązanie wspólnoty językowej do własnego języka i kultury może - mimo niesprzyjających wcześniej regulacji - wymusić uznanie ich przez państwo, na którego terytorium ta wspólnota się znajduje.

Język walijski został uznany już po drugiej wojnie światowej, jednak jego użycie w życiu oficjalnym (sądy, administracja) nawet po wejściu w życie Welsh Language Act z 1967 r. było bardzo ograniczone. Działacze w Walii szybko zdali sobie sprawę z tego, że język nie zostanie ożywiony, jeśli ludzie nie będą go używać i to we wszystkich sferach. Jednak niewiele osób decydowało się korzystać ze swoich (początkowo ograniczonych) praw do używania walijskiego, obawiając się, czy kompetencja językowa pozwala im na posługiwanie się nim w oficjalnych sytuacjach, czy zostaną zrozumiani i zaakceptowani. Bardzo wielu walijskojęzycznych mieszkańców Walii w ogóle nie zdawało sobie sprawy z tego, 
że możliwość używania tego języka w życiu publicznym w ogóle istnieje. Co więcej, jako osoby dwujęzyczne uważali, że łatwiej i szybciej jest załatwiać wszystkie sprawy po angielsku. Trzy akty (The Education Act z 1988 r., The Welsh Language Act z 1993 r. i The Government of Wales Act z 1998 r.), dotyczące edukacji, praw językowych i rządzenia, były ważnym punktem wyjścia do działań uświadamiających ludziom ich prawa i możliwości w zakresie posługiwania się językiem walijskim. Powołano więc do życia instytucje i organizacje zajmujące się wdrażaniem planu językowego w Walii, zaczynając od poziomu podstawowego - pokazania zwykłym ludziom możliwości używania języka walijskiego w życiu pozadomowym.

The Welsh Language Board, najważniejsza walijska instytucja, stała się organem odpowiedzialnym za zwiększenie liczby mówiących po walijsku, za rozszerzenie możliwości używania tego języka, za zmianę przyzwyczajeń językowych i zachęcanie ludzi do wzięcia udziału w proponowanych działaniach, wreszcie za wzmocnienie pozycji walijskiego jako języka społeczności. Główny ciężar działań położono na kooperację i aktywne współdziałanie lokalnych organizacji i indywidualnych działaczy. Przy pomocy Mentrau Iaith (agencji językowej) próbowano zachęcić i przekonać ludzi znających walijski do używania go, między innymi tworząc specjalne miejsca, gdzie można używać języka walijskiego, promując go we współpracy z lokalnymi działaczami, organizacjami i pojedynczymi osobami, wprowadzając do sfer biznesowych, promując dwujęzyczność w pracy, zachęcając tych, którzy mówią słabo lub już nie mówią w ogóle po walijsku, do kontynuowania pracy nad językiem, udzielając praktycznej pomocy dorosłym, którzy chcą się nauczyć walijskiego, ułatwiając kontakty między mówiącymi po walijsku i pomagając im w określeniu ich potrzeb językowych. Do zadań agencji należy również praca nad materiałami pomocniczymi do nauki walijskiego, udzielanie informacji o lokalnych możliwościach edukacji po walijsku, a także wsparcie lokalnej przedsiębiorczości (Williams 2000, s. 45).

Zdając sobie sprawę, że wszyscy w Walii są dwujęzyczni, a więc w każdej sytuacji mogliby posługiwać się bez problemu językiem angielskim, zainicjowano pracę animatorów językowych (linguistic animateurs), którzy mieli czynnie wspierać dwujęzyczność na poziomie lokalnym. Animatorzy zaczęli pracować jako pracownicy socjalni, pielęgniarki, pomoce domowe, zostali zatrudnieni w policji, w opiece społecznej, w straży pożarnej czy karetkach pogotowia. Ich rola polegała na ustanawianiu nowego dwujęzycznego podłoża, przygotowywaniu gruntu pod wdrożenie w miejscach pracy projektów językowych (Williams 2000 , s. 48-49). Stworzono także programy wspomagające rodziców chcących wychować swoje dzieci dwujęzycznie, przez udzielanie im szeregu porad, a także udostępnianie materiałów, takich jak płyty $\mathrm{CD}$ z piosenkami dla dzieci po walijsku, dwujęzyczne książki dla dzieci, a także materiały z historiami o życiu i sukcesach innych rodzin wychowujących swoje dzieci w dwujęzyczności (Edwards 2004, s. 89). 
Oczywiście nie można przecenić roli edukacji dwujęzycznej, która została wprowadzona w Walii na mocy Education Reform Act z 1988 r., dając wszystkim w Walii prawo do nauki w języku walijskim, a pozostałym — obowiązek uczenia się walijskiego jako języka obcego. Dzięki takim działaniom, nastawionym na zaszczepienie $\mathrm{w}$ Walii dwujęzyczności, udało się zahamować odchodzenie od języka walijskiego, a dzięki promocji tego języka — zaszczepić go nawet na tych terenach, które od dawna pozostawały wyłącznie angielskojęzyczne.

Brak organizacji zajmującej się polityką językową odczuwany jest na Łużycach. Łużycki jest przykładem języka w zasadzie nieobecnego w życiu publicznym, mimo że chroni go prawo Saksonii i Brandenburgii i uznany został za język współoficjalny na terytorium, na którym występuje. Co więcej, Niemcy ratyfikowały Europejska karte języków regionalnych lub mniejszościowych, w której uwzględniono oba języki łużyckie (dolno- i górnołużycki), a kolejne raporty uznawane są przez Radę Europy. Choć Łużyczanie mają oficjalnie prawo do nauki w tym języku (i tego języka), a także do posługiwania się nim w życiu oficjalnym i publicznym, wciąż nie jest to możliwe z powodu braku personelu, który byłby w stanie zrozumieć język łużycki. Winę za taki stan ponoszą też sami Łużyczanie, którzy często nie są świadomi możliwości posługiwania się łużyckim w sferach pozadomowych albo nie są przekonani co do możliwości załatwiania po łużycku ważnych spraw. Choć podjęto wiele programów ratujących ten ginący język (takich jak projekt edukacji poprzez immersję Witaj), brakuje oddolnych działań zachęcających mniejszość do posługiwania się nim.

Nie umniejszając ważnej roli instytucji naukowych i edukacyjnych, należy powiedzieć, że istniejące organizacje w dużej mierze koncentrują się na utrzymaniu status quo tego języka, na organizowaniu imprez folklorystycznych, nie przykładając wystarczającej uwagi do potrzeb młodych ludzi, którzy znają język łużycki z domu lub ze szkoły, a chcieliby się nim posługiwać w innych sytuacjach życiowych, niekoniecznie związanych z obcymi im często praktykami kultury tradycyjnej. Za politykę językową na Łużycach odpowiedzialne są skupiająca łużyckich działaczy, instytucje i stowarzyszenia organizacja Domowina oraz Centrum Językowe Witaj, które jednak ogranicza swoją działalność do sfery edukacyjnej. Wyraźnie brakuje organu, który koncentrowałby działania na szerzeniu dwujęzyczności na Łużycach. Pomysł stworzenia takiej instytucji poddał Ludwig Elle w książce Minderheitensprache und Wirtschaft (2002), zwracając uwagę właśnie na fakt, że brak osobnej organizacji, która zajmowałaby się wdrażaniem polityki językowej, powoduje, że wciąż znajduje się ona w dużej mierze w sferze projektów. Pomysł stworzenia „Biura ds. dwujęzyczności” na wzór dobrze działającego Welsh Language Board ${ }^{7}$ nie spotkał się jednak z wystarczającym odzewem.

7 Do zadań „Biura” należałoby: udzielanie porad i informacji co do możliwości używania języka łużyckiego, wspieranie łużyckojęzycznych uczniów i absolwentów (np. pomoc w znalezieniu pracy, w której mogliby wykorzystywać znajomość łużyckiego), opracowanie projektów ochrony języka łużyckiego oraz pomoc w przedsięwzięciach turystycznych, działania mające na celu podnoszenie 
Dlatego też język łużycki został niemal całkowicie zepchnięty do poziomu przekazu nieoficjalnego, domowego, ewentualnie używany jest jako środek komunikacji w zamkniętych wspólnotach (np. na zebraniach i spotkaniach organizacji łużyckich). Coraz więcej osób znających język łużycki z różnych przyczyn nie decyduje się na przekazanie go swoim dzieciom. Niestety, brak silnych bodźców, uświadomienia ludziom prawa do mówienia w ich ojczystym języku, a także działań zachęcających do rzeczywistego korzystania ze swoich praw językowych, powoduje, że coraz mniej osób posługuje się tym językiem, traktując go jako nieużyteczny. Przykład ten potwierdza, że choć wsparcie państwa i rola edukacji są ważnymi czynnikami w odrodzeniu języka, nie można od nich oczekiwać, że same odwrócą zmienioną już językową sytuację (May 2001, s. 141).

W przypadku języków mniejszościowych na terytorium państwa, które $\mathrm{w}$ ogóle nie uznaje (lub uznaje $\mathrm{w}$ bardzo ograniczonym zakresie) prawa do posługiwania się językiem innym niż oficjalny, cały ciężar działań „odwracania zmiany językowej” musi być położony na lokalne akcje zachęcania członków kultur mniejszościowych do posługiwania się własnym językiem. Przykładem może być język bretoński we Francji, która nie uznaje istnienia na swoim terytorium mniejszości kulturowych ani językowych. Mimo to Bretończycy włączyli się w ruch odrodzenia etnicznego i począwszy od lat siedemdziesiątych dokonała się znaczna zmiana ich samoświadomości, której towarzyszy chęć nauki języka bretońskiego i wdrażanie lokalnych działań mających na celu pokazanie ludziom, że język ten da się jeszcze uratować. Na terytorium Bretanii działają setki stowarzyszeń proponujących działania animacyjne skłaniające lokalne wspólnoty do mówienia w języku bretońskim. Działania dotyczą głównie aktywności artystycznej i wypełniającej wolny czas (jak rozpowszechnione imprezy fest-noz, uczestnictwo w kółkach celtyckich, różnych programach oraz zajęciach dla uczestników wspólnot bretońskojęzycznych). Wprowadzono również dwujęzyczną i immersyjną edukację, która jednak z braku oficjalnego wsparcia finansowego, a także wobec nieprzychylnej polityki państwowej, nie jest bardzo rozpowszechniona. Nawet małe działania pokazujące żywotność języka i kultury sprawiają jednak, że coraz więcej osób czuje potrzebę ratowania języka i przyłącza się do wspólnych inicjatyw. Dotkliwy jest brak możliwości rzeczywistego zastosowania języka bretońskiego w życiu pozaprywatnym. A bez pokazania wartości i użyteczności języka trudno przekonać do inwestowania czasu i pieniędzy w jego naukę. W 1999 r. w Bretanii zostało założone Biuro Języka Bretońskiego (Ofis ar Brezhoneg/Office de la langue bretonne). Dzięki jego pracom, analizom i prognozom językowym, a przede wszystkim dzięki konkretnym działaniom mającym na celu propagowanie używania ję-

prestiżu języka łużyckiego w życiu publicznym i gospodarczym, przybliżanie Łużyczan do nowoczesnych mediów informatycznych, opracowywanie dwujęzycznych formularzy i dokumentów, tworzenie projektów polityki językowej, wyznaczanie jej celów; zob. Elle 2002, s. 53-58. 
zyka bretońskiego (np. akcja „Spilhening” ${ }^{8}$, kampania „Ya d'ar brezhoneg”9), jak również dzięki pełnieniu funkcji organu odpowiedzialnego za politykę językową Bretanii (konsultacje, podpisywanie umów, na przykład z Microsoftem w sprawie bretońskojęzycznej wersji Vista i Office), Biuro okazało się oparciem i pomocą dla prac prowadzonych przez środowiska stowarzyszeniowe Bretanii.

Siła i spektakularność bretońskiego ruchu, a także to, że przyciąga coraz więcej ludzi może stać się powodem chocby częściowej zmiany oficjalnej polityki państwa, tak jak pod koniec lat siedemdziesiątych, kiedy została podpisana Karta kultury bretonskiej (Charte culturelle bretonne), na mocy której utworzono oficjalne organizacje wspierające kulturę bretońską ${ }^{10}$. Pod koniec 2004 r. Rada Regionu Bretanii uznała język bretoński i gallo za oficjalne języki regionu ${ }^{11}$. Działacze bretońscy, często w porozumieniu z przedstawicielami innych mniejszości językowych Francji, silnie lobbują na rzecz zagwarantowania we Francji praw i ochrony języków mniejszościowych i choć na razie działania te nie przyniosły wystarczających efektów (Francja uznała Europejską karte jezyków za sprzeczną z francuską konstytucją, co uniemożliwia, jej zdaniem, ratyfikację dokumentu), można odczuć powolną zmianę oficjalnego nastawienia do problemu mniejszości zamieszkujących terytorium kraju.

Tych kilka przykładów nie wyczerpuje oczywiście problemu, pokazuje jednak, że przychylność państwa wobec mniejszości językowych znajdujących się na jego terytorium odgrywa ogromną rolę w procesie „odwracania zmiany językowej”, ale także że postawa państwa nie jest decydująca. Ustawodawstwo ma ogromne znaczenie nie tylko dla sankcjonowania podstawowych praw językowych, ale także dla stworzenia odpowiedniej infrastruktury, w której te prawa mogą być wypełniane. Bardzo często jednak prawa teoretycznie przy-

8 Biuro Języka Bretońskiego, wzorując się na akcji prowadzonej w Walii rozpoczęło w 2007 r. kampanię znaczków „Spilhening”, co w języku bretońskim oznacza „mała broszka”. Znaczki, które byłyby noszone przez wszystkich znających bretoński, są dostępne i identyczne w całej Bretanii. Ich przypięcie daje znak, że dana osoba mówi po bretońsku.

9 Kampania „Ya d'ar brezhoneg” została zapoczątkowana w 2001 r. w związku z europejskim rokiem języków. Działania pierwszego etapu były skierowane do aktorów życia ekonomicznego, głównie do firm. Celem było przekonanie ich, aby wprowadzili język bretoński do codziennego funkcjonowania. Do tej pory kartę podpisało ponad 600 struktur, reprezentujących społeczeństwo bretońskie w całej jego złożoności: wśród sygnatariuszy znajdują się oczywiście stowarzyszenia, ale także wiele firm, handlowców, syndykatów, klubów sportowych, mediów. Drugi etap kampanii rozpoczął się w 2004 r., tym razem skierowany był do wspólnot terytorialnych. Celem było wprowadzenie bretońskiego do życia publicznego. Agencja proponuje wspólnotom 28 konkretnych działań, na przykład dwujęzyczna sygnalizacja drogowa, dwujęzyczne nagrania na automatycznej sekretarce $\mathrm{w}$ merostwie czy dwujęzyczne strony internetowe, jak również wprowadzanie oficjalnych ceremonii w języku bretońskim, szkolenia dla urzędników czy wsparcie rozwoju dwujęzycznej edukacji. Za: Charte Ya d'ar brezhoneg. Pour le développement durable du breton dans les communes.

10 Conseil Culturel de Bretagne (Kuzul Sevenadurel Breizh), Institut Culturel de Bretagne (Skol Uhel ar Vro), Agence technique culturelle régionale de Bretagne.

${ }^{11}$ Ma to wartość czysto symboliczną, nie pociąga za sobą żadnych konkretnych działań ze strony państwa, wzmacnia jednak związek regionu z językiem i przyczynia się do nagłośnienia problemu. 
sługujące mniejszościom językowym pozostają formalnym zapisem, nie są respektowane ze względu na niedostateczne uświadamianie ludziom możliwości wyboru języka. Wprowadzenie dwujęzyczności wymaga więc nie tylko odpowiednich paragrafów, ale przede wszystkim zaangażowania wszystkich tych, których te prawa dotyczą. Rolą państwa jest więc z pewnością zapewnienie mniejszości językowej prawa do zakładania organizacji, umożliwienie prowadzenia dwujęzycznej edukacji, dotacje na wydawnictwa i programy w języku mniejszościowym, wreszcie umożliwienie używania języka mniejszościowego w różnych sferach życia publicznego - w urzędach, biurach, na poczcie, w sądzie czy u lekarza. Przy czym do najważniejszych zadań samej wspólnoty językowej musi należeć stworzenie aktywnej i dobrze zorganizowanej siatki stowarzyszeń i animatorów, niezależnych od aparatu państwowego, którzy byliby gotowi upowszechniać $\mathrm{w}$ bezpośrednich działaniach używanie języka mniejszościowego i uwidaczniać jego istnienie. „Istnienie organizacji «trzeciego sektora" (niezależnych od rządu i biznesu) jest konieczne zwłaszcza wtedy, gdy istnieje oficjalny sprzeciw wobec stanowiska, że polityka rewitalizacji jest pożądana i potrzebna. Gdy państwo jest zaangażowane w politykę rewitalizacji, takie organizacje stwarzają przydatny pomost między wspólnotą językową a odgórną polityką państwową" (Grin, Villancourt 1999, s. 99). Państwu bowiem nie musi zależeć na zachowaniu wielojęzyczności na swoim terytorium, gdyż z pewnością wymaga to wielu nakładów finansowych i pociąga za sobą komplikacje administracyjne. Rząd może - i powinien - ustanowić stosowne prawa i postanowienia, nie jest jednak w stanie (i chyba nie jest to jego rola) nakłonić jednostek do używania na co dzień języka mniejszościowego. To zadanie, najbardziej odpowiedzialne i najtrudniejsze $\mathrm{w}$ procesie odwracania zmiany językowej, należy właśnie do przedstawicieli mniejszości językowych. Niejednokrotnie zaś zorganizowane działania ze strony mniejszości, ich zaangażowanie i rzeczywiste używanie języka mniejszościowego mogą doprowadzić do zwrócenia uwagi przedstawicieli państwa na problemy danej mniejszości, a w konsekwencji do rozszerzania jej praw, a nawet oficjalizacji języka.

\section{BIBLIOGRAFIA}

Abalain Hervé, 2000, Historie de la langue bretonne, Jean-Paul Gisserot, Luçon.

Broudic Fañch, 1995, La pratique du breton de l'Ancien Régime à nos jours, Presses Universitaires de Rennes, Rennes.

Crystal Dawid, 2005, Language Death, Cambridge University Press, Cambridge.

Dorian Nancy C., 1998, Western Language Ideologies and Small-Language Prospects, w: Lenore A. Grenoble, Lindsay J. Whaley (red.), Endangered Languages: Current Issues and Future Prospects, Cambridge University Press, Cambridge.

Edwards John, 1992, Sociopolitical Aspect of Language Maintenance and Loss: Towards a Typology of Minority Language Situations, w: Willem Fase, Koen Jaspaert, Sjaak Kroon (red.), Maintenance and Loss of Minority Languages, Benjamins, Amsterdam. 
Edwards Viv, 2004, Multilingualism in the English-speaking Word: Pedigree of Nations, Blackwell Publishing, Oxford.

Elle Ludwig, 2002, Minderheitensprache und Wirtschaft. Möglichkeiten zur Einbeziehung des Sorbischen in die ökonomische und administrative Praxis, Sorbisches Institut/Serbski institut, Bautzen/Budyšin.

Fishman Joshua A., 1987, Language Spread and Language Policy for Endangered Languages, $\mathrm{w}$ : Proceedings of the Georgetown University Round Table on Language and Linguistics, Georgetown University Press, Washington.

Fishman Joshua A., 1989, Language and Ethnicity in Minority Sociolinguistic Perspective, Multilingual Matters LTD, Clevedon.

Fishman Joshua A.,1991, Reversing Language Shift: Theoretical and Empirical Foundations of Assistance to Threatened Languages, Multilingual Matters, Clevedon.

Fishman Joshua A. (red.), 2001, Can Threatened Languages be Saved? Reversing Language Shift, Revisited: A $21^{\text {st }}$ Century Perspective, Multilingual Matters LTD, Clevedon.

Goebl Hans, Nele Peter H., Starý Zdeněk, Wölck Wolfgang (red.), 1996, Kontaktlinguistik. Ein internationales Handbuch zeitgenössischer Forschung / Contact Linguistics: An International Handbook of Contemporary Research / Linguistique de contact. Manuel international des recherches, Walter de Gruyter, Berlin.

Grenoble Lenore A., Whaley Lindsay J. (red.), 1998, Endangered Languages: Current Issues and Future Prospects, Cambridge University Press, Cambridge.

Grin François, Villancourt François, 1999, The Cost-effectiveness Evaluation of Minority Language Policies: Case Studies on Wales, Ireland and the Basque Country, European Centure for Minority Issues, ECMI Monograph \#2, Flensburg.

Grin François, 2003, Language Policy Evaluation and the European Charter for Regional or Minority Languages, Palgrave Macmillan, New York.

Hagège Claude, 2000, Halte à la mort des languages, Odile Jacob, Paris.

Hinton Leanne, Hale Ken (red.), 2001, The Green Book of Language Revitalization in Practice, Academic Press, San Diego.

Hyltenstam Kenneth, Stroud Christopher, 1996, Language Maintenance, w: Hans Goebl i in. (red.), Kontaktlinguistik. Ein internationales Handbuch zeitgenössischer Forschung / Contact Linguistics: An International Handbook of Contemporary Research / Linguistique de contact. Manuel international des recherches, Walter de Gruyter, Berlin.

Krauss Michael, 1992, The World's Languages in Crisis, „Language”, t. 68, nr 1.

Martí Fèlix, Ortega Paul, Idiazabal Itziar, Barreña Andoni, Juaristi Patxi, Junyent Carme, Uranga Belen, Amorrortu Estibaliz (red.), 2005, Words and Worlds: World Language Review, UNESCO Extea, Multilingual Matters, Clevedon-Buffalo-Toronto.

May Stephen, 2001, Language and Minority Rights: Ethnicity, Nationalism and the Politics of Language, Pearson Education, Harlow.

Nettle Daniel, Romaine Suzanne, 2000, Vanishing Voices: The Extinction of the World's Languages, Oxford University Press, New York.

Różyca Małgorzata, 2003, Problem tożsamości kulturowej mniejszości narodowych z perspektywy państwa, w: Mieczysław Trojan (red.), Ich małe ojczyzny. Lokalność, korzenie $i$ tożsamość $w$ warunkach przemian, Uniwersytet Wrocławski, Katedra Etnologii i Antropologii Kulturowej, Wrocław.

Skutnabb-Kangas Tove, Phillipson Robert (red.), 1995a, Linguistic Human Rights: Overcoming Linguistic Discrimination, Mouton de Gruyter, Berlin. 
Skutnabb-Kangas Tove, Phillipson Robert, 1995b, Linguistic Human Rights, Past and Present, w: Tove Skutnabb-Kangas, Robert Phillipson (red.), Linguistic Human Rights: Overcoming Linguistic Discrimination, Mouton de Gruyter, Berlin.

Skutnabb-Kangas Tove, Phillipson Robert, 1996, Linguicide and Linguicism, w: Hans Goebl i in. (red.), Kontaktlinguistik. Ein internationales Handbuch zeitgenössischer Forschung / Contact Linguistics: An International Handbook of Contemporary Research / Linguistique de contact. Manuel international des recherches, Walter de Gruyter, Berlin.

Šatava Leoš, Hose Susanne (red.), 2000, Papers from the International Workshop: Maintenance, Revitalisation and Development of Minority Languages. Theoretical Basis and Practical Measures. Workshop Bautzen/Budyšin, 16.-17. April 1999, Serbski institut, Bautzen / Budyšin.

Trojan Mieczysław (red.), 2003, Ich małe ojczyzny. Lokalność, korzenie i tożsamość w warunkach przemian, Uniwersytet Wrocławski, Katedra Etnologii i Antropologii Kulturowej, Wrocław.

Williams Colin H., 2000, Community Empowerment and Language Revitalisation: Practical and Succesful Initiatives in Wales, w: Leoš Šatava, Susanne Hose (red.), Papers from the International Workshop: Maintenance, Revitalisation and Development of Minority Languages. Theoretical Basis and practical Measures. Workshop Bautzen/Budyšin, 16.-17. April 1999, Serbski institut, Bautzen / Budyšin.

Wurm Stephen, 1998, Methods of Language Maintenance and Revival, with Selected Casus of Language Endangerment in the Word, w: Kazuto Matsumura (red.), Studies in Endangered Languages, Hituzi Syobo, Kioto.

\section{POSSIBILITIES FOR THE REVITALISATION OF ENDANGERED LANGUAGES: BETWEEN THE RESPONSIBILITY OF COUNTRIES AND THE ACTION TAKEN BY LANGUAGE MINORITIES}

\section{Summary}

The article considers the main ways, aims and possibilities of revitalising minority languages. The discussion is based on an analysis of a few minority languages (Welsh, Wendi's and Breton) and the action being taken in order to keep them alive. The author asks the question as to the degree to which minority cultures and their rights to minority languages are respected by the state and the significance of this to the revitalisation of seriously endangered languages. Her answer is that the most effective method of protecting endangered languages is to support action conducted by representatives of the minority cultures, which will improve the standing of that language and will encourage its use in public life and - at least partly - on official occasions (not forgetting about the introduction of those languages into the education system).

Key words/Słowa kluczowe

minority languages / języki mniejszościowe; state language policies / polityka językowa państwa 